\title{
DERLEME
}

\section{Radyasyon Güvenliğinde Mesleki Olarak Bilmemiz Gerekenler}

\section{Need To Knows About Radiation Safety Vocationally}

\author{
F. Dilek Gökharman ${ }^{1}$, Sonay Aydın ${ }^{1}$ Pınar N. Koşar ${ }^{1}$
}

${ }^{1}$ Ankara Eğitim ve Araştırma Hastanesi, Radyoloji Anabilim Dalı, Ankara,Türkiye.

\section{Özet}

Tanısal radyolojide radyasyon güvenliği, sadece doza maruz kalan hasta için değil bu ortamda çalışan radyasyon görevlisi için de sağlanması gereken zorunluluk olup; ulusal ve uluslararası kurumlar tarafindan oluşturulan sinırlar çerçevesinde gözetilir. $\mathrm{Bu}$ nedenle radyasyonla çalışan bireylerin temel düzeyde radyasyon güvenliğini bilmesi, hem kendi sağlığı hem de günlük pratik uygulamalar sırasında karşılaşacakları olası problemlerin çözümünde önem taşımaktadır. $\mathrm{Bu}$ çalışmada radyasyonun tanımı, radyasyon kaynakları ve tipleri, temel radyasyon doz birimleri, radyasyon alanları ve radyasyonun zararlı etkilerinin neler olduğu, radyasyondan korunma kurumları, radyasyon güvenliği tüzüğü ve yönetmeliği bilgileri güncel verilerle gözden geçirilecektir.

Anahtar kelimeler: Radyasyon Güvenliği, Diagnostik Radyoloji

\section{Giriş}

\section{Radyasyon nedir?}

Radyasyon atomlardan enerji yayılımı ve transferi olarak tanımlanmakta ve elektromanyetik dalga özelliklerini göstermektedir (şekil 1). Enerjisi frekans ile doğru; dalga boyu ile ters orantilidir $(1,2)$.

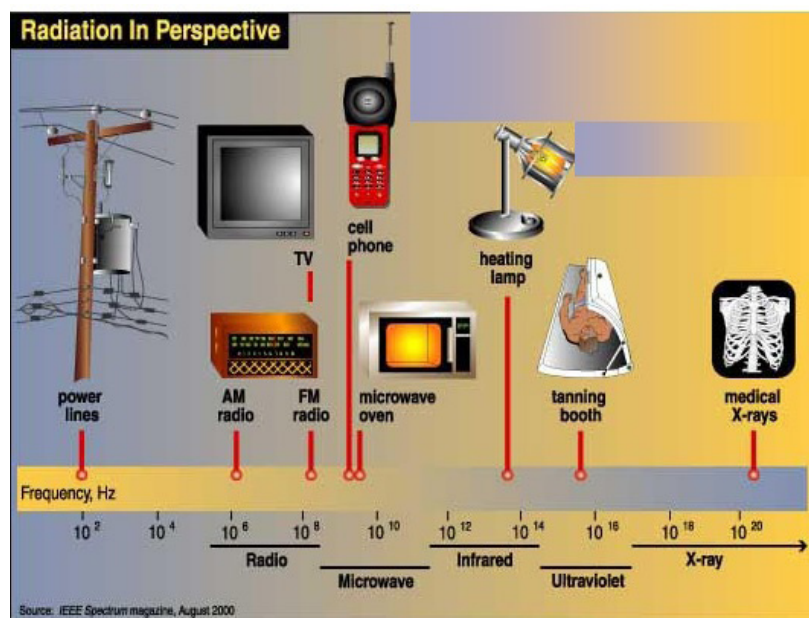

Şekil 1: Elektromanyetik spektrum.

\begin{abstract}
In diagnostic radiology, radiation safety is important for both patients and staff. Radiaton safety has certain criteria which are stated by both national and international foundations. Staff who works in radiation areas needs to know basic principles about radiation safety, so that they can protect themselves and solve daily problems more easily.

In this review; we try to summarise up-to-date informations about definition of radiation, sources of radiation, types of radiation, basic radiation dose units, radiation fields, harmful effects of radiation, radiation protection foundations, radiation safety rules and regulations.
\end{abstract}

Key words: Radiation Safety, Diagnostic Radiology

\section{Radyasyon kaynakları nelerdir?}

Radyasyon doğal veya yapay kaynaklı olabilir:

\section{a- Doğal radyasyon nedir? Doğal radyasyon kaynakları} nelerdir?

Doğal kaynaklı maruz kalınan radyasyondur. En önemli sebebi, yer kabuğunda bulunan radyoaktif radyum elementinin (Ra226) bozunması sırasında salınan "radon gazı"dır. Radon gazından dolayı dünya genelinde maruz kalınan ortalama doz $1.3 \mathrm{mSv} / \mathrm{y} ı l$ 'dır. Gama 1şınları ve kozmik 1şınlar kaynaklı doğal radyasyon dozunun dünya ortalaması sirasıyla 0.46 $\mathrm{mSv} / \mathrm{y}$ 1l ve $0.39 \mathrm{mSv} / \mathrm{y}$ ll'dır. Yiyecek, içecek ve solunan hava ile maruz kaldığımız radyasyonun dünya ortalaması yaklaşık $0.25 \mathrm{mSv} / \mathrm{y} ı l$ 'dır. Doğal radyoaktif elementlerden Potasyum-40 nedeni ile maruz kaldığımız ortalama radyasyon dozu ise $0.23 \mathrm{mSv} / \mathrm{y} 1$ 'dır $(3,4)$.

\section{b-Yapay radyasyon nedir? Kaynakları nelerdir?}

Tıbbi, zirai ve endüstriyel amaçla kullanılan $\mathrm{X}$ ışınları ve yapay radyoaktif maddeler sonucunda maruz kalınan radyasyondur. Bunlar içinde tıbbi uygulamalar en önemli neden olup; yapay radyasyon kaynağının \%95'den fazlasını oluşturur. Yapay radyasyonla halkın maruz kaldığ 1 yıllık radyasyon dozunun dünya ortalaması $0.3 \mathrm{mSv}$ 'tir (4).
Yazışma Adresi: Sonay Aydın,

Ankara Eğitim ve Araştırma Hastanesi, Radyoloji Kliniği, Altındağ, Ankara, Türkiye. Tel: 05066259155

E-mail: sonaydin89@hotmail.com
Müracaat tarihi: 01.06.2016

Kabul tarihi: 24.06 .2016 
Tablo 1. Radyasyon dozunun eski ve yeni birimleri.

\begin{tabular}{|c|c|c|c|}
\hline TERİM & \multicolumn{2}{|c|}{ BİRIMİ } & \multirow[t]{2}{*}{ DÖNÜŞÜM } \\
\hline & ESKİ & YENI & \\
\hline $\begin{array}{l}\text { IŞINLANMA } \\
\text { DOZU }\end{array}$ & $\begin{array}{l}\text { Röntgen }(\mathrm{R}) \text {; normal hava şartlarında }\left(\mathrm{O}^{0} \mathrm{C}\right. \\
\text { ve } 760 \mathrm{~mm} \text { Hg basıncı) havanın } 1 \mathrm{~kg} \text { 'ında } \\
258 \times 10^{-4} \text { Coulum'luk elektrik yükü } \\
\text { değerinde }(+) \text { ve }(-) \text { iyonlar oluşturan } \mathrm{X} \\
\text { veya Y radyasyonu miktarıdır. }\end{array}$ & $\begin{array}{l}\text { Coulomb / kilogram }(\mathrm{C} / \mathrm{kg}) \text {; normal hava } \\
\text { şartlarında havanın } 1 \mathrm{~kg} \text { 'ında } 1 \text { Cou- } \\
\text { lomb'luk elektrik yükü değerinde }(+) \text { ve } \\
\text { (-) iyonlar oluşturan X veya Y radyasyonu } \\
\text { miktarıdır. }\end{array}$ & $\begin{array}{l}1 \mathrm{C} / \mathrm{kg}=3876 \mathrm{R} \\
1 \mathrm{R}=2.58 \times 10^{-4} \\
\mathrm{C} / \mathrm{kg}\end{array}$ \\
\hline $\begin{array}{l}\text { SOĞURULMUŞ } \\
\text { DOZ }\end{array}$ & $\begin{array}{l}\text { Radiation absorbed doz (rad); 1şınlanan } \\
\text { maddenin } 1 \text { kg'ında } 10^{-2} \text { Joule'lük enerji } \\
\text { soğurulması meydana getiren herhangi bir } \\
\text { radyasyon miktarıdır. }\end{array}$ & $\begin{array}{l}\text { Coulomb / kilogram }(\mathrm{C} / \mathrm{kg}) \text {; normal hava } \\
\text { şartlarında havanın } 1 \mathrm{~kg} \text { 'ında } 1 \text { Cou- } \\
\text { lomb'luk elektrik yükü değerinde }(+) \text { ve } \\
\text { (-) iyonlar oluşturan X veya Y radyasyonu } \\
\text { miktadır. }\end{array}$ & $\begin{array}{l}1 \mathrm{~Gy}=100 \mathrm{rad} \\
1 \mathrm{rad}=0.01 \mathrm{~Gy}\end{array}$ \\
\hline DOZ EŞDEĞERİ & $\begin{array}{l}\text { Röntgen eguevalent man (rem); } 1 \\
\text { Röntgen'lik } \mathrm{X} \text { veya } \mathrm{Y} \text { 1şını ile aynı } \\
\text { biyolojik etkiyi oluşturan herhangi bir } \\
\text { radyasyon miktarıdır. } \\
\text { Rem }=(\mathrm{rad}) \mathrm{x}\left(\mathrm{W}_{\mathrm{R}}\right)^{*}\end{array}$ & $\begin{array}{l}\text { Sievert }(\mathrm{Sv}) ; 1 \text { Gy’lik } \mathrm{X} \text { ve } \mathrm{Y} \text { ışını ile aynı } \\
\text { biyolojik etkiyi meydana getiren herhangi } \\
\text { bir radyasyon miktarıdır. } \\
\mathrm{Sv}=(\mathrm{Gy}) \mathrm{x}\left(\mathrm{W}_{\mathrm{R}}\right)^{*}\end{array}$ & $\begin{array}{l}1 \mathrm{~Sv}=100 \mathrm{rem} \\
1 \mathrm{rem}=0.01 \mathrm{~Sv}\end{array}$ \\
\hline
\end{tabular}

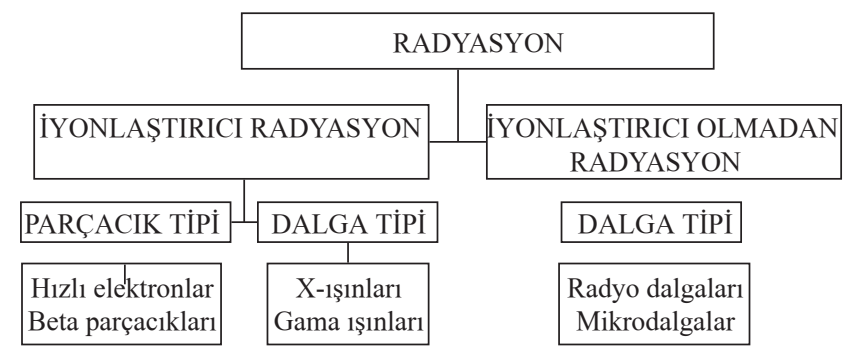

Şekil 2: Radyasyon çeşitleri.

\section{Radyasyon tipleri nelerdir?}

Radyasyon iyonizasyon oluşturan ve iyonizasyon oluşturmayan radyasyon olarak sınıflanmaktadır (şekil 2).

1. İyonizasyon oluşturan (iyonize) radyasyon; karşılaştığ atomun yörüngelerinden elektron kopararak iyon çiftleri oluşturan radyasyondur. Parçacık ve dalga tipi olmak üzere ikiye ayrılır: a) parçacık tipi radyasyon: Belirgin bir kütle ve enerjiye sahip çok hızlı hareket eden parçacıkları ifade eder. Alfa ve beta tipi radyasyon bu grubun en bilinen tipleridir. b) dalga tipi radyasyon: Belli bir enerjiye sahip ancak kütlesiz radyasyon çeşididir. Bu grupta $\mathrm{X}$ ve gama 1şınları bulunup; farkları X ışının atomu çevreleyen elektron bulutunda, gama ışınının ise atomun çekirdeğinde meydana gelmesidir (5).

2. İyonizasyon oluşturmayan radyasyon (noniyonize radyasyon); etkileşime girdiği maddede iyonlar oluşturmayan radyasyondur. Radyo dalgaları, mikro dalgalar, kızıl ve mor ötesi 1ş1k ve görünür 1ş1k bu tip radyasyon örnekleridir $(5,6)$.

$\mathrm{Bu}$ yazıda ağırlıklı olarak tanısal uygulamalarda kullanılan X 1şını kaynaklı radyasyondan söz edilecektir.

\section{Temel radyasyon doz birimleri nelerdir?}

Maruz kalınan radyasyon düzeyini ölçmek, karşılaştırabilmek ve maruziyet sonucu olabilecek zararlı biyolojik etkilerin tahmininde kullanmak için yıllar içinde aşağıda tanımlanan temel radyasyon doz birimleri oluşturulmuştur $(6,7)$. (Tablo $1)$.

Işınlama Dozu: X-ışınlarının havada yaratacağı etkinin büyüklügünü ifade eden dozimetrik bir kavramdır. Işınlama dozu eski birimi "Röntgen" (R) ; uluslarası (SI) birimine göre ise "Coulomb/ kilogram"dır (C/kg).

Soğurulmuş Doz: Bir maddenin birim kütlesinde soğurulan herhangi bir radyasyon enerjisi miktarını göstermekte için kullanılır. Eski birimi "rad", yeni birimi ise "Gray" (Gy)'dir.

Eşdeğer Doz: Belli bir radyasyon çeşidinin yaratacağ biyolojik etkiyi ifade eder. Soğurulmuş dozun o radyasyon çeşidinin ağırlık katsayısı (radiation weigthing factor, WR) ile çarpılması ile hesaplanır. Tipta kullanılan radyasyon çeşitlerinin çoğu için WR 1 kabul edilir. Eski birimi "rem"; yeni birimi "Sievert" (Sv)'tir.

Etkin Doz: Doku veya organların aldığı dozun tüm vücut için yüklediği riski ifade etmek için kullanılan bir kavramdır. Her organ ve doku için ayrı bir organ doz ağırlık katsayısı (tissue weigthing factor, WT) vardır (Tablo 2). Her organ veya

Tablo 2. Organ ve dokular için değişen doz ağırlık katsayılar

\begin{tabular}{llll}
\hline ORGAN / DOKU & $\mathrm{W}_{\mathrm{T}}$ & ORGAN / DOKU & $\mathrm{W}_{\mathrm{T}}$ \\
\hline Kemik iliği & 0.12 & Akciğer & 0.12 \\
Mesane & 0.05 & Ösefagus & 0.05 \\
Kemikyüzeyi & 0.01 & Deri & 0.01 \\
Meme & 0.05 & Mide & 0.12 \\
Kolon & 0.12 & Tiroid & 0.05 \\
Gonad & 0.20 & Diğer & 0.05 \\
Karaciğer & 0.05 & & \\
\hline (W $\mathrm{T}_{\mathrm{T}}$ doku ağrllı faktörü) & &
\end{tabular}


Tablo 3. Radyasyon çalıșanları ve toplum üyesi kișiler için doz sinirlar1.

\begin{tabular}{|c|c|c|c|}
\hline & & $\begin{array}{l}\text { Radyasyon } \\
\text { çalışanları }\end{array}$ & $\begin{array}{l}\text { Toplum } \\
\text { Üyeleri }\end{array}$ \\
\hline \multirow[t]{2}{*}{$\begin{array}{l}\text { Etkin Doz } \\
\text { Sinırı }\end{array}$} & $\begin{array}{l}\text { Ardışık } 5 \text { yılın } \\
\text { Ortalaması }\end{array}$ & $20 \mathrm{mSv}$ & $1 \mathrm{mSv}$ \\
\hline & $\begin{array}{l}\text { Herhangi bir } \\
\text { y1lda }\end{array}$ & $50 \mathrm{mSv}$ & $5 \mathrm{mSv}$ \\
\hline \multirow{3}{*}{$\begin{array}{l}\text { Yıllık } \\
\text { Organ } \\
\text { Eşdeğer } \\
\text { Doz Sınırı }\end{array}$} & Göz Merceği & $150 \mathrm{mSv}$ & $15 \mathrm{mSv}$ \\
\hline & Deri $\left(\mathrm{cm}^{2}\right)$ & $500 \mathrm{mSv}$ & $50 \mathrm{mSv}$ \\
\hline & Eller ve Ayaklar & $500 \mathrm{mSv}$ & $50 \mathrm{mSv}$ \\
\hline \multicolumn{2}{|c|}{$\begin{array}{l}\text { Hamile Çalışanın } \\
\text { Abdomen Eşdeğer doz Sınırı }\end{array}$} & $\begin{array}{l}\text { Hamileliğin } \\
\text { Bildirilmesini } \\
\text { Takiben } 1 \\
\text { mSv }\end{array}$ & - \\
\hline
\end{tabular}

dokunun maruz kaldığı eşdeğer doz, WT ile çarpılır ve çıkan sonuç tüm vücudun aldığ 1 toplam etkin dozu verir . Birimi "Sv" 'tir.

Radyasyon çalışanları ve halk için belirlenen doz sınırları Tablo 3'de özetlenmiştir.

\section{Radyasyon alanları nelerdir?}

Hastane ve benzeri sağlık kuruluşlarında maruz kalınacak yıllık dozun $1 \mathrm{mSv}$ değerini geçme olasılığı bulunan alanlar radyasyon alanı olarak kabul edilir. Maruz kalınan doza göre radyasyon alanları denetimli ve gözetimli alanlar olarak ikiye ayrilir (8).

Denetimli alanlar (controlled area): Giriş ve çıkışların özel denetime ve çalışmaların radyasyon korunması bakımından özel kurallara bağlı olduğu alanlardır. Bu alanlarda çalışanlar, ardışık 5 yılın ortalamasının 3/10'nunu geçen radyasyon dozuna maruz kalabilir. Denetimli alanlarda radyasyona maruz kalma tehlikesinin büyüklügünü ve özelliklerini gösteren uyarı işaretleri (şekil 3) kullanılmalı, koruyucu giysi ve kişisel dozimetri kullanılmalı ve görev yapanların hematolojik tetkikleri yılda en az bir kere yapılmalıdır.
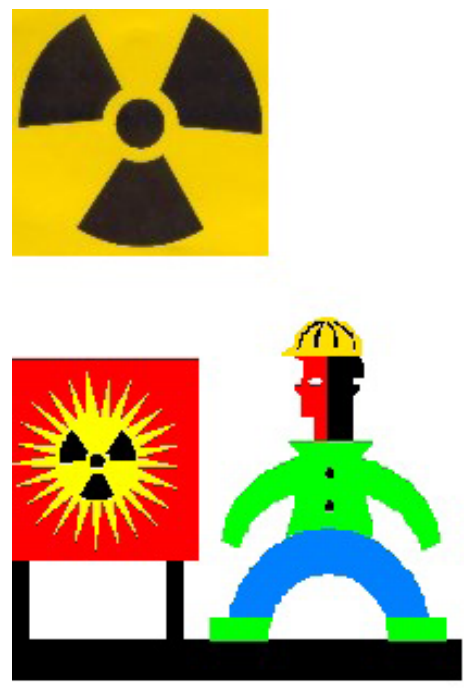

Şekil 3: Radyasyon uyarı işaretleri.
Tablo 4. Radyasyon duyarlığına göre hücrelerin sınıflandırılması

\begin{tabular}{ccc}
\hline Yüksek RD & Orta RD & Düşük RD \\
\hline Kemik iliği & Deri & Kaslar \\
Dalak & Mezoderm & Kemikler \\
Timus bezi & organlar & Sinir sistemi \\
Lenf nodülleri & (Akciğer, & \\
Gonadlar & karaciğer, kalp,..) & \\
Göz merceği & & \\
Lenfositler & & \\
\hline
\end{tabular}

Gözetimli alanlar (supervised area): Radyasyon görevlileri için yıllık doz sınırlarının 1/20'sinin aşılma olasılığı olup; 3/10'nunun aşılması beklenmeyen alanlardır. $\mathrm{Bu}$ alanlarda kişisel doz ölçümü gerekmezken çevresel radyasyonun izlenmesi gerekir. Hamileliği belirlenmiş radyasyon görevlileri de ancak gözetimli alanlarda çalıştırılır. Fetusu korumak amacıyla hamile radyasyon görevlisinin batın yüzeyi için hamilelik boyunca ilave eșdeğer doz sınırı 1 mSv'dir (8).

\section{Radyasyonun zararlı etkileri nelerdir?}

Radyasyonun neden olduğu biyolojik hasar, radyasyonun tipine ve enerjisine, hedef tarafindan soğurulan doza, bu dozun alındığı süreye ve canlı dokunun (hedefin) özelliklerine bağlı olarak değişir (8). Biyolojik hasarı etkileyen faktörler arasında, doku özellikleri (oksijen konsantrasyonu yüksek dokularda hassasiyet fazladır), hücre bölünme sıklığg ve metabolik aktivitesi (Tablo 4), doku tarafindan absorbe edilen doz miktarı, bu dozun absorblanma süresi sayılabilir (3).

Radyasyon dokularda direkt ve indirekt biyolojik hasarlanma oluşturabilir. Radyasyonun direkt etkisi, radyasyon enerjisinin doğrudan biyolojik hedef olan DNA tarafından absorbe edilmesidir. DNA'da oluşan hasar genetik şifrede kalıtsal değişikliklere neden olur. Radyasyonun indirekt etkisi, radyasyon enerjisinin biyolojik sistemin içinde bulunduğu ortamın molekülleri tarafından absorbe edilmesi ile oluşur (şekil 4). İndirekt etkide su molekülü iyonizasyonu ile oluşan hidrojen peroksit gibi serbest radikaller aracılığıyla DNA zedelenmesi ortaya çıkar (9).

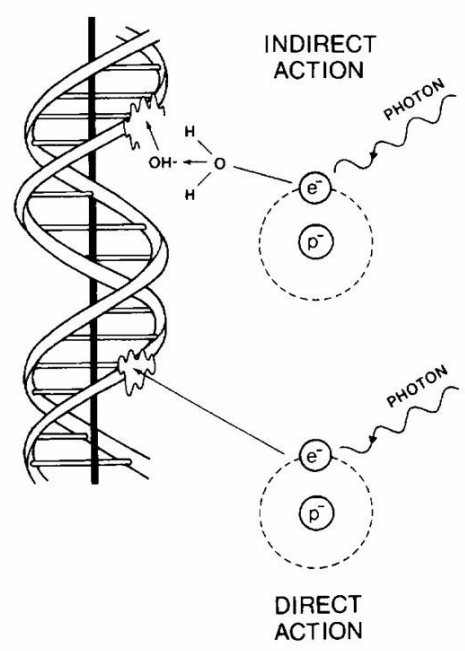

Şekil 4: Radyasyonun direkt ve indirekt etkileri 
Radyasyonun direkt ve indirekt olarak oluşturduğu hücresel hasar deterministik yada sitokastik etkilerle sonuçlanır. Deterministik etkiler: Radyasyonun dozunun şiddeti ile doğru orantılı olup; etkinin ortaya çıkabilmesi için eşik doz değeri aşılmalıdır. Katarakt oluşumu, cilt yanıkları, geçici ya da sürekli kısırlık deterministik etkilerdendir. Örneğin göz merceğinin, uzun yıllar boyunca y1llık olarak 0.1 Sv'in üzerinde bir doza maruz kalması gözde fark edilebilir bir opasiteye neden olurken; bu doz 0.15 Sv'in üzerine çıktığında katarakt meydana gelebilir.

Sitokastik etkiler: Aralıklı olarak düşük dozlara maruz kalınması sonucu ortaya çıkar. Etkinin şiddeti dozdan bağımsızdır ancak doz arttıkça etkinin olma olasılığg da artar. Bunlar karsinojenik etkiler (lösemi akciğer, meme, kemik tümörleri), doğal ömrün kısalması, kalıtımsal etkiler, doğurganlığın azalması olarak siralanabilir $(9,10)$.

\section{Radyasyondan korunma kurumları nelerdir?}

Kuramsal olarak miktarı ne olursa olsun, radyasyonun herhangi bir dozunun kanser meydana getirme olasılığ vardır. Örneğin hamilelikte radyasyonun oluşturduğu riski belirlemekte doz önemli olmakla birlikte; dozdan bağımsız sitokastik etki göz ardı edilmemelidir. Ancak bu olasılıkların çok düşük olması nedeniyle bu varsayımın ispatlanması mümkün değildir. deterministik-sitokastik etkilerden radyasyon çalışanları ile halkı koruma ve bilinçlendirme amaçlı ulusal ve uluslarası radyasyondan korunma kurumları oluşturulmuştur. Bu konuda çalışan ilk kurum, Uluslarası Radyolojik Korunma Komisyonu (ICRP) olup, 1928 yılında Stockholm'de kurulmuştur . Radyasyondan korunmada, Birleşmiş Milletler Atomik Radyasyonun Etkileri Bilimsel Komitesi (UNSCEAR), Uluslararası Atom Enerjisi Ajansı (IAEA), Avrupa Atom Enerjisi Topluluğu (EURATOM), Uluslaras1 Radyasyon Birimleri Komisyonu (ICRU), Dünya Sağlık Örgütü (WHO), Uluslararası Standartlar Organizasyonu (IS0) gibi uluslararası başka birçok kuruluş bulunmaktadır (8).

ICRP, radyasyon çalışanları ve halkın maruz kaldığı düşük dozların etkileri ile ilgili sürekli veriler toplamakta ve bu verilere dayanarak sitokastik etkileri için belli aralıklarla risk tahminleri yayınlamaktadır. $\mathrm{Bu}$ risk seviyelerine dayanarak, radyasyon çalışanları ve halk için doz sınırları belirlenmektedir (Tablo 3). Ülkemizde ise bu görevi Türkiye Atom Enerjisi Kurumu (TAEK) üstlenmiş olup; radyasyon güvenliğine ilişkin ilke, önlem ve hukuki sorumluluk sınırlarını belirleyen tüzük ve yönetmelikleri hükümete sunmakta, bunların yasalaştırılmasını sağlamakta ve uygulamaları denetlemektedir (8).

\section{Radyasyon güvenliği tüzüğü ve yönetmeliği nedir?}

Radyasyon güvenliği tüzüğü; iyonlaştırıcı radyasyon kaynaklarını bulunduran, kullanan, imal, ithal ve ihraç eden, alan, satan, taşıyan ve depolayan, resmi ve özel kurum ve kuruluşlar ile gerçek kişilerle ilgili sorumluluk esaslarını belirler. Genel hükümler, görevler ve yetkiler, temel standartlar, lisans, izin, denetim, çeșitli hükümler alt başlıklarında bu esasların sınırları çizilmiş̧tir.

Radyasyon güvenliği yönetmeliği; radyasyon güvenliğinin sağlanmasını gerektiren her türlü tesis ve radyasyon kaynağının zararlı etkilerinden kişileri ve çevreyi korumak için alınması gereken her türlü tedbir ve yapılması gereken uygulamaları kapsar $(4,5,10,12)$.

\section{Radyasyon güvenliğinde sorumluluklar nelerdir?}

Tıbbi 1şınlamalarda uygulamaların gerekçelendirilmesi ve optimizasyon ilkelerinin uygulamasından hastane yönetimleri, lisans sahibi ve uygulama alanında çalışan kişiler sorumludur.

\section{Lisans sahibi veya tesis sahibi:}

i) radyasyon güvenliğine ilişkin standartların ve yasaların uygulanmasını sağlamak,

ii) yıllık doz sınırları üzerinde etkin doza maruz kalmayı gerektiren durumlarda her türlü önlemi almak ve ışınlanacak kişileri uyarmak,

iii) çalışmaların riskine göre uygun radyasyon görevlilerini çalıştırmakla yükümlüdür.

\section{Radyasyon Korunması Sorumlusu:}

i) uygun radyasyon ölçüm cihazlarının bulundurulmasını ve kullanılmasını sağlamak,

ii) radyasyondan korunma ile ilgili ölçüm programlarını hazırlamak ve uygulamak zorundadır.

TAEK lisans alınmasının yanı sıra çalışan, hasta ve çevrenin korunmasıveradyasyonkaynaklarınıngüvenliğininsağlanması amaciyla, hastanelerden radyasyon güvenliği komitesini (RGK) oluşturulması istenmiştir (13). Başhekimlik, RGK örgütlenmesini sağlamak ve yetkilendirmekle sorumludur. Bu komitede hastane yönetimi, radyoloji, radyasyon onkolojisi, nükleer tıp, kardiyoloji ve endokrin laboratuarı bölümleri temsilcileri, hemşirelik hizmetleri sorumlusu, teknik hizmetler sorumlusu, halk sağlığı temsilcisi görev almalıdır. RGK görev ve sorumlulukları;

i) Uygulamalarda TAEK' in radyasyon güvenliği mevzuatını yerine getirmek,

ii) Hastane içinde radyasyondan korunma konusunda politikalar oluşturmak,

iii) Radyasyon güvenliği programları hazırlamak, aksayan yönleri saptamak ve yenilemek,

iv) Hastanede bulunan radyasyon kaynaklarının envanterini tutmak ve denetlemek,

v) Kullanılan radyasyon kaynaklarına ilişkin güvenlik analizlerinin yapılmasinı ve raporlarının tutulmasinı sağlamak,

vi) Tutulan kayıtları ve hazırlanan raporları incelemek ve değerlendirmektir (13).

\section{Radyasyon güvenliği felsefesi nedir?}

Ülkemizde uygulanan Radyasyon Güvenliği Tüzük ve Yönetmelikleri, ICRP'nin radyasyon korunması bakımından ortaya koyduğu 3 temel ilkeye dayanmaktadır (8);

a) Uygulamanın gerekliliği (Justification): Işınlamanın 
zararlı sonuçları göz önünde bulundurularak fayda sağlamayan hiçbir radyasyon uygulamasına izin verilemez.

b) Optimizasyon: Tedavi amaçlı tıbbi ışınlamalar hariç; radyasyon ışınlamasını gerektiren uygulamalarda, mümkün olan en düşük dozun alınması sağlanmalıdır. Bu olabildiğince düşük doz (as low as achievable possıble ALARA) prensibi olarak bilinir.

c) Doz sınırları: Mesleği gereği radyasyonlarla çalışanlar ve halk için yıllık alınmasına izin verilen doz sınırlarıdır (Tablo 3). Görevi gereği radyasyona maruz kalan kişilerin, aldıkları radyasyon dozu sıkı bir şekilde kontrol ve takip edilmelidir . Tıp alanında çalışan radyasyon görevlilerinin aldıkları dozun yıllık ortalaması 1 - $5 \mathrm{mSv}$ arasında olmalıdır.

\section{$X$ ışını uygulamalarında temel güvenlik yöntemleri nelerdir?}

$\mathrm{X}$ ışını uygulamalarında temel güvenlik prensipleri, hem hastayı hem de radyasyon personelini korumayı hedefler. En yüksek radyasyon dozunu hasta almakla birlikte; personel kendi aldığı dozun hastanın aldığı doz ile orantılı olduğunu bilerek davranmalıdır (5).

\section{Radyasyon dozunun kontrolü;}

- X 1şını kaynağında: sızıntının ve saçılan radyasyonun önlenmesi, radyolojide kullanılan cihazların düzenli aralıklarla kalite kontrol ve güvenlik denetimleri yapılması ile,

- cihazın bulunduğu çevrede çekim odasında yeterli havalandırma ve kumanda ünitesi önündeki paravanın, hastaların giriş/çıkış yaptığı kapının ve radyoloji ünitesinin bulunduğu duvarların kurşunla kaplanarak yapısal zırhlamanın sağlanması ile,

- çalışan personelde kurşun önlük gibi koruyucu giysi kullanılması ve doz takibi yapılması ile sağlanabilir.

Koruyucu giysi; 100 kVp'nin altında çalışanlar için $0.25 \mathrm{~mm}$, $100 \mathrm{kVp}$ üstünde çalışanlar için $0.35 \mathrm{~mm}$ kalınlığında olmalıdır(8).Ana zırhlama malzemesi kurşun önlük olup, tiroid koruyucu, gonad koruyucu ve kurşun eşdeğeri camdan yapılmış gözlük, eldiven, zırhlamanın diğer parçalarıdır. Kurşun gözlüklerin $0.75 \mathrm{~mm}$ kurşun eşdeğeridir.

Kişisel ölçüm cihazları (dozimetreler); film dozimetre, termoluminesans dozimetre (TLD), optik dozimetreler, cep iyonizasyon odacıkları ve diğer küçük radyasyon dedektörlerinden oluşur. Genellikle $0.1-0.2 \mathrm{mSv}$ 'in üzerindeki dozları ölçerler. Doz değerlerinin yüksek beklenmesi durumunda iki dozimetre kullanılmalı ve ilk dozimetre önlük altında bel seviyesinde; 2 . dozimetre ise önlük üstünde boyun seviyesinde kullanilır $(5,8,11)$.

Hem çalışan hem de hastanın maruz kaldığ azaltmak için yapılabilecek en etkili yöntemlerden bir diğeri ise tanısal radyolojide kullanılan yüksek radyasyon maruziyetini en aza indirmektir. X sşını keşfinden ve klinik alanda kullanılışından bu yana günümüze kadar geçen sürede, $\mathrm{X}$ ışınlarının film üzerinde görüntü oluşturma prensiplerinde bir değişiklik olmamasına rağmen cihazlardaki teknolojik gelişmelere paralel hasta dozunda 100 kattan daha fazla azalma olmuştur (6). Bu doz azalması sağlanırken görüntü kalitesinden ödün verilmemesi amaçlanmıștır. Radyasyon dozunu azaltmak için aşağıda özetlenecek dengelerin gözetilmesi esastır $(4,6)$ :

1. Kilovoltaj $(\mathrm{kVp}): \mathrm{kVp}$ yükseltildikçe saçılan 1şın miktarı da artacağından görüntüdeki kontrast azalır. $\mathrm{Bu}$ nedenle $\mathrm{kVp}$ optimum görüntü kalitesi ile en düşük radyasyon dozu kombinasyonunun elde edileceği en yüksek değerde seçilmelidir.

2. Tüp akımı (mA) ve ışınlama süresi (mAs): Optimum radyografik dansitenin elde edilmesi $\mathrm{mAs}$ seçimi ile gerçekleşmektedir. Ancak mAs'taki artış, hastanın aldığı dozu artırır.

3. Filtrasyon: X 1şını demetinin önündeki toplam filtrasyon ile demetin çok düşük enerjili kısmı hastaya ulaşmadan durdurulmaktadır. Böylece demetin kVp'si ve ışının giriciliği arttırılarak çıkış dozunda önemli bir farklılık olmadan girişderi dozu azaltılmış olur.

4. Kolimasyon: Fokal spot boyutu inceleme yapılacak hastaya ve incelenecek bölgenin yapısına göre seçilmelidir .

5. Grid: Saçılan 1şınların kontrolünü sağlarken primer 1şını da soğurduğundan daha yüksek 1şınlama faktörleri kullanmak gerekir ki bu da hastanın aldığı dozu artırır.

6. Film-ekran kombinasyonu: Ekran tarafindan salınan ışığın dalga boyu ile film hassasiyeti birbirine uygun olmalıdır.

7. Film-banyo teknikleri: Karanlık oda gün 1şı̆̆ından tümüyle yalıtılmış olmalıdır. Ancak günümüzde kullanıma giren computerize röntgen (CR) ve dijitalize röntgen (DR) uygulamaları, karanlık oda gereksinimini ortadan kaldırmıştır.

\section{Sonuç:}

Personel eğitimi, detaylı prosedürlerin hazırlanması, ergonomik tasarımların kullanılması, oluşturulan korunma ve güvenlik sisteminin işlerliğinin sağlanması radyasyon güvenliğinde istenmeyen olayların ortaya çıkmasını engelleyecektir.

\section{Kaynaklar}

1. Brateman L. The AAPM/RSNA Physics Tutorial for Residensts Radiation Safety Considerations for Diagnostic Radiology Personel. Radiographics 1999: 1037-1055.

2. Bushong SC. Radiologic Science for Technologists. The Mosby Company 3rd ed. The C. V. Mosby Company 1984: 138-144.

3. 1990 Recommendations of the ICRP. ICRP Publication 60. Pergamon Press 1991.

4. http:// www.taek.gov.tr (Erişim tarihi: 01.06.2016)

5. Togay YE. Radyasyon Ve Biz . Türkiye Atom Enerjisi Kurumu Yayınları. 2002: 2-12.

6. İnce MZ. Tanisal Radyolojide Radyasyondan Korunma Türkiye Atom Enerjisi Kurumu Yayınları. 2002: 2-34.

7. CJ. Martin and D.G. Sutton. Oxford Practical Radiation 
Protection in Health Care. Medical Publications 2006: $27-$ 42.

8. International Basic Safety Standards for Protection Against Ionizing Radiation and for the Safety of Radiation Sources, Safety Series 115, IAEA, 1994.

9. Özalphan A. Temel Radyobiyoloji. Haliç Üniversitesi Yayınları 1. Basım 2001; 1-33. 10. Bor D, Buyan G, Meriç

N. Tanısal Radyolojide Radyasyondan Korunmada Yeni Kavramlar 2. Radyoloji Gündemi 2000: 5-10.

11. Togay YE. Tanisal Radyolojide Radyasyondan Korunma.
Türkiye Atom Enerjisi Kurumu Yayınları 2002; 2-20.

12. Pabuşcu Y. Türkiye'nin Radyasyon Kaza ve Savaşına Karşı Durumu ve Radyasyon İle İlgili Yasal Durum. Temel Radyoloji Fiziği. Türk Radyoloji Derneği İzmir Şubesi Eğitim Sempozyumları 2004-2005: 133-141.

13. Balcı P. Radyasyon Güvenliği Komiteleri Kuruluş Görev Ve Etkinlikleri.Temel Radyoloji Fiziği. Türk Radyoloji Derneği İzmir Şubesi Eğitim Sempozyumları 2004-2005: 142-146. 